\title{
A Comparison on the Effects of Teaching Literature Between Literary and Non-literary Secondary School Students
}

\author{
Salah Edin Hassan Elobeid Mohamed \\ Qassim University/ Saudi Arabia, Department of English language \\ Supervised by: Dr. Abdulgadir Mohammed Ali \& Dr. Mohammed Tayib Abdullah
}

\begin{abstract}
The study attempts to investigate the effect of literature on the performance of Sudanese Secondary Schools Students. The study aims precisely to (1) to measure the performance of the students of thinking, (2) to measure the students' vocabulary, (3) to measure the way in which the students write. Further, the study attempts to rectify the assumptions that literature does not contribute to language learning and that; (there is no relation comparison between the students who study literature with those who don't). To achieve the aims of this study, the researcher conducted an experiment on two groups of Sudanese secondary schools students. The students in one group were exposed to literature and the students in the second group were not. The students in the two groups were given a twenty minutes written test. The test was designed to measure the effects of being exposed to literature on the performance of the students. The study concludes that the learning of literature influences on the students positively to a large extent. The students who study literature are better in all language skills and they think creatively compared with those who don't.
\end{abstract}

Keywords: assumption, comparison / experiment, written test , literature influences.

\section{Introduction}

Literature according to Gillian (1993) is described as a world of fantasy, horror, feelings, and visions . . . Put into words. It means to meet a lot of people, to know other different points of view, ideas, thoughts, minds . . . to know ourselves better".As for Bennet and Royle, 1995, p.191)."Literature serves to provide an exquisite excitement of emotions and a very deep insight into the nature of reality. It translates various experiences of life into various patterns and thus helps readers discover meaning in their lives. It provides them with insight to deal with the people and world around them. The literary world is regarded as a mingling of fact and fiction." The students are supposed to make use of their study of literature to develop their language proficiency.

Murat (2005) presented a paper titled "Teaching English Through Literature". This paper aims at emphasizing the use of literature as a popular technique for teaching both basic language skills. The author concluded that Literature is not only a tool for developing the written and oral skills of the students in the target language but also is a window opening into the culture of the target language, building up a cultural competence in students.

Elyagot (2012)conducted a research under the title"Using Literature to Develop Reading Comprehension Skills", The main purpose of the researcher in this study to find out the role of using literature in developing reading comprehension skills. The findings of the study indicate that literature helps students to develop reading comprehension skills and vocabulary. In another studybyMunazza( 2007 ), conducted an experimental study titled "Developing Creative Thinking: in which he proved that, literature helps to develop creative thinking.
Dr. Qareeballah and Dr.Sarwar(in their study titled "Teaching Language through Literature: A diagnostic study on the teaching of English as a Foreign Language" utilized two different syllabi for teaching English language Skills. Group A was exposed to a language syllabus that contained canonical instructions and exercises on language skills with little or no exposure to literary discourse. Group B, on the other hand, was exposed to an experimental syllabus that included the different literary genres such as excerpts from novels, short stories, drama and poetry.The researchers conclude that literature or literary texts can play a vital role in developing language skills among the non- native learners of English and helping them to use language for communicative purposes in the real world.

In this study the researcher made a comparison between two types of students. The students who studied literature and the ones who didn't study it. He described the methodology used to conduct this paper and he had illustrated the way in which he accomplished the study. The first to be discussed the subjectsandthetool that were used to collect data.

This study includes detailed descriptions of the population accompanied by figures and tables. The validity and reliability of comparisons between the two levels of the students were verified.

\section{Setting and Population}

The setting of the paper was two secondary schools. The population of the study was (100) secondary school students (females) who used to study English for more than six years. They were chosen randomly from two schools that happened to be in Omdurman district.

The schools follow the National Policy of Education for Sudan. The National Curriculum, Framework for School Education, Sudan Department of Education (2015). 


\section{International Journal of Science and Research (IJSR) \\ ISSN (Online): 2319-7064 \\ Index Copernicus Value (2013): 6.14 | Impact Factor (2014): 5.611}

The subjects in the research have been studying English as a second language for more than six years. That is to say, the students had some prior knowledge of English language and they were able to answer the questions of the test. The researcher divided them into two groups according to their knowledge of literature.

A (100) secondary school students were chosen from two schools in different areas. The students who were chosen to conduct this experiment were studying at the $3^{\text {rd }}$ level. All the female students who participated in this study were the same age and level. The students were divided into two groups. That is to say, the literal group consists of (50) Students and the non-literal group also consists of the same number of students.

The participants share these characteristics:

1) They are the same age.

2) They are in the same level $\left(3^{\text {rd }}\right.$ secondary school).

3) The same location (Omdurman district in Sudan).

4) They are all Sudanese female students.

5) The students in both schools were randomly chosen.

\section{Method}

The tool used in this study is a written test given to secondary school students.

\section{Tools' Reliability}

Validity refers to the extent to which the data collection procedure measures what it intends to measure. To measure the reliability of the tools used in the study, the researcher followed these points:

1) The use of (SPSS) computer programme to analyze the data.

2) A test was distributed to (100) students.

\section{Instruments}

\section{Procedures: Data collection}

The data were collected through observations, interviews and tests. According to Fetterman (1998) and Shank (2002) data collection was seen as qualitative method that provides sufficient detail for thick description. The students were chosen from two different school and they were given the same test. In each school (50) students participated in answering all the questions of the test. Then the papers were collected and each paper got a score. The written interviews were distributed individually and randomly to group of directors of English language. The researcher interviewed most of them in their own offices and benefited, to a large extent, from their experience in the field of education. They were helpful and polite and after the interview the researcher expressed to them his gratitude and thankfulness.

\section{Data Analysis}

The analysis involved searching for comparisons between the students who were exposed to literature to the ones who didn't study any literary texts.

\section{Students' test results}

Table 1: Students 'creative thinking results

\begin{tabular}{|c|c|c|c|}
\hline \multirow{2}{*}{ Literature Study } & \multicolumn{2}{|c|}{ Results } & \multirow{2}{*}{ Total } \\
\cline { 2 - 3 } & Pass & Fail & \\
\hline Yes & 48 & 2 & 50 \\
\hline No & 22 & 28 & 50 \\
\hline Total & 70 & 30 & 100 \\
\hline
\end{tabular}

(,Yes ${ }^{\text {ee }}$ stands for the students who studied literature and „No ${ }^{\text {ee }}$ stands for those who didn"t.)

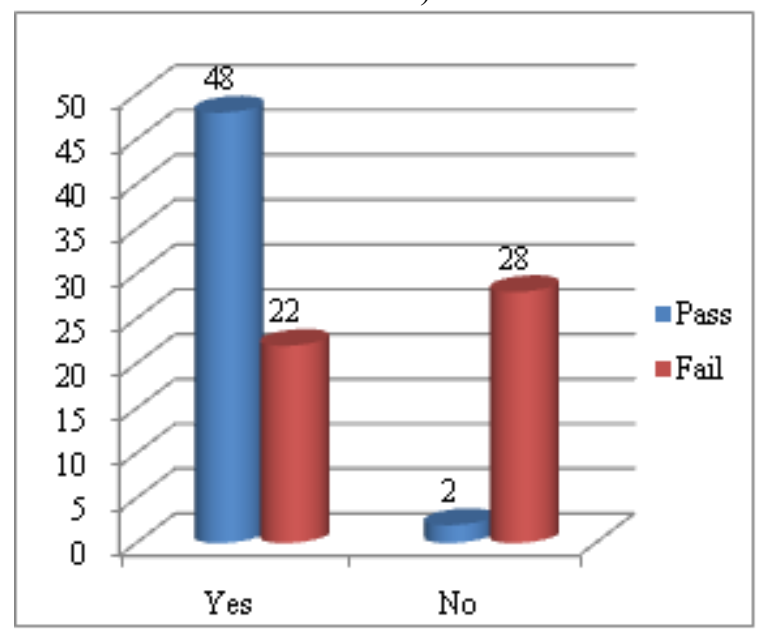

Figure 1: Students ${ }^{\text {ee }}$ creative thinking results

When we talk about creative thinking, it is to be noticed that and from the above table and figure the results of the students who studied literature were better compared with those who didn't. 48 out of 50 students who studied literature passed the test and only 2 students failed. On the other hand, 22 out of 50 students who studied literature passed the test while 28 students failed in it.

Table 2: Students ${ }^{\text {ee }}$ vocabulary results

\begin{tabular}{|c|c|c|c|}
\hline Literature Study & \multicolumn{2}{|c|}{ Results } & \multirow{2}{*}{ Total } \\
\cline { 2 - 3 } & Pass & Fail & \\
\hline Yes & 45 & 5 & 50 \\
\hline No & 41 & 9 & 50 \\
\hline Total & 85 & 14 & 100 \\
\hline
\end{tabular}

(,Yes ${ }^{\text {ee }}$ stands for the students who studied literature and „No ${ }^{\text {ee }}$ stands for those who didn ${ }^{e t}$.)

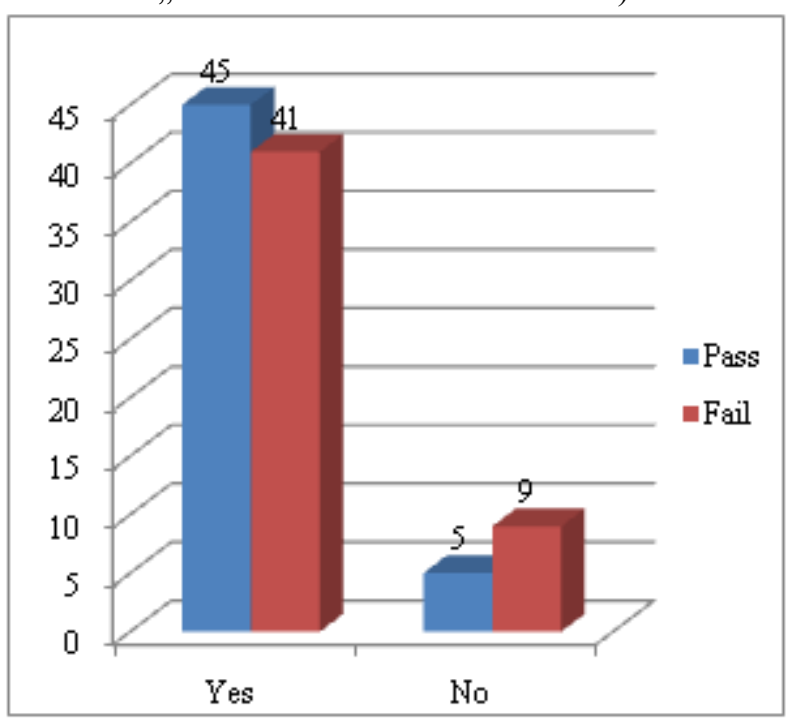

Figure 2: Students "e vocabulary results 


\section{International Journal of Science and Research (IJSR) \\ ISSN (Online): 2319-7064 \\ Index Copernicus Value (2013): 6.14 | Impact Factor (2014): 5.611}

„Yes ${ }^{e c}$ stands for the students who studied literature and „No stands for the students who didn't.

When we talk about the students "e vocabulary results, it is to be noticed that and from the above table and figure, the results of the students who studied literature were better compared with those who didn't.45 out of 50 students who studied literature passed the test while only 5 students failed. On the other hand, 41 out of 50 students who didn't study literature passed the test while 9 students failed in it

Table 3: Students ${ }^{\text {ee }}$ writing results

\begin{tabular}{|c|c|c|c|}
\hline Literature Study & \multicolumn{2}{|c|}{ Results } & \multirow{2}{*}{ Total } \\
\cline { 2 - 3 } & Pass & Fail & \\
\hline Yes & 19 & 31 & 50 \\
\hline No & 5 & 45 & 50 \\
\hline Total & 24 & 76 & 100 \\
\hline
\end{tabular}

(,Yes ${ }^{\text {ee }}$ stands for the students who studied literature and ,No ${ }^{\text {ee }}$ stands for those who didn ${ }^{e q}$.)

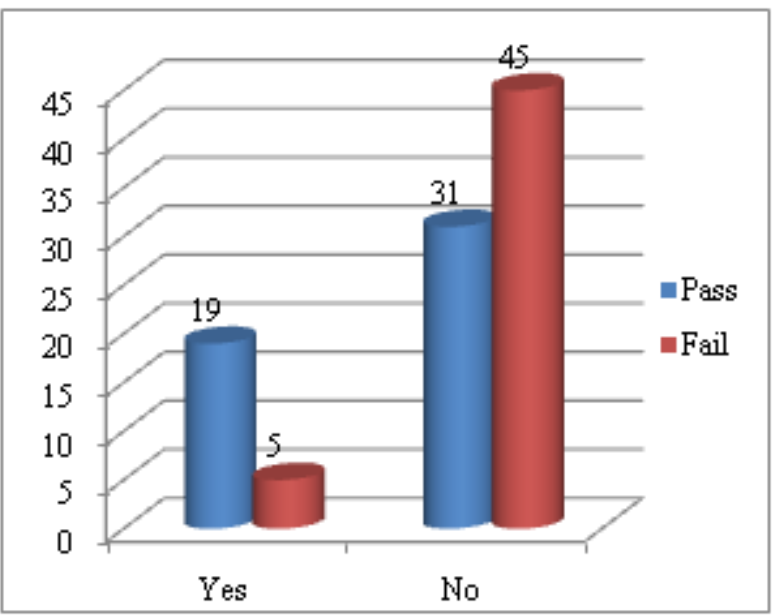

Figure 3: Students ${ }^{\text {ee }}$ writing results

Concerning the students ${ }^{\text {ee }}$ writing results and from the above table and figure, it is to be noticed that the results of the students who studied literature were better compared with those who didn't. 19 out of 50 students who studied literature passed the test while 31 students failed. On the other hand, the students who didn't study literature, only5out of 50 students passed the test while 45 students failed in it.

\section{Conclusions}

(Brumfit and Carter( 1986) says that: 'As far as 'literary' studies are concerned, students also acquaint themselves with the nature of literary discourses and therefore are studying literature in a very primary and essential sense."

The study does reveal the importance of literature teaching in all levels, but more research is needed. It was to investigate the importance of literature by comparing the degrees scoured by the students in both schools.

The study is an attempt and a contribution in an area that deals with literature which had been neglected by many educational centres. This study illustrates that literature reading enabled the students to achieve better results in performance tests or in communication situations. The findings of the analysis of the study have confirmed the findings of the previous studies, especially that literary students are better learners in terms of oral communication and performance. It concludes that, the study of literature influences on the students positively to a large extent. The future researches may support or extend the findings concerning the importance of literature on performance, thinking and education of students. That is to say, the teaching of literature should be included in all educational curricula for its necessity and importance.

\section{Summary of Findings}

The analysis of the obtained results of the study provided the following findings:

1) The teaching of literature in schools is very important.

2) The students who were exposed to literature scoured higher marks compared with those who weren $\mathrm{t}$ exposed to any literary text.

3) The students who studied literature emphasized the importance role that it plays in promoting the studentse linguistic ability and fluency.

4) The written test emphasized that the students who study literature are better thinkers compared with those who don't.

5) The literary students have a powerful vocabulary compared with non-literary students.

\section{References}

[1] Bennett, A and Royle, N. Introduction to Literature, Criticism, and Theory. Second edition:Harlow: Pearson, 1999

[2] Brumfit, $\mathbf{C}$ and Carter, R. Literature and Language Teaching: New York: Oxford University, 1986.

[3] Elyagot,M".Using Literature to Develop Reading Comprehension www.sustech.edu,2012.

[4] Fetterman, D.M. (1998). Ethnography: Step by step. (2nd Ed.). Thousand Oaks, CA: Sage.

[5] Hamdoun, H . Qareeballah, and. Syed, H.S Teaching Language through Literature: A diagnostic study on the teaching of English as a Foreign Language": Website.

[6] Lazar, G . Literature and Language Teaching: A Resource Book for Teacher and Trainers :London: Cambridge University Press, 1993.

[7] Murat .Teaching English ThroughLiterature".Journal of Language and LinguisticStudies, Vol.1, No.1, April 2005.

[8] Shank, G. D. (2002). Qualitative research: A personal skills approach. Columbus, Ohio:

[9] Yaqoob ,M . Developing Creative Thinking : Cognitive Approach To The Teaching Of English: National University Of Modern Languages , Islamabad, December 2007

\section{Author Profile}

Merrill Prentice Hall is Salah Edin Hassan Elobeid Mohamed, Department of English language, Qassim University/ Saudi Arabia $/ \mathrm{E}-$

\section{Volume 4 Issue 11, November 2015}

